\title{
Alcohol use and risk of vehicle accidents: cross-sectional study in the city of São Paulo, Brazil
}

\author{
Janaina Barbosa de Oliveira', Florence Kerr-Corrêa", Ícaro Caresia Lopes'"', Walter Vitti Junior"v, \\ Hélio Rubens de Carvalho Nunes ${ }^{v}$, Maria Cristina Pereira Limav \\ Faculdade de Medicina de Botucatu (FMB), Universidade Estadual Paulista (UNESP), Botucatu (SP), Brazil
}

PhD. Psychologist, Centro de Estudos da Educação e da Saúde/Centro Especializado em Reabilitação (CEES/CER II), Universidade Estadual Paulista (UNESP), Marília (SP), Brazil.

(D) orcid.org/0000-0002-8551-3125

"PhD. Psychiatrist and Full Professor, Department of Neurology, Psychology and Psychiatry, Faculdade de Medicina de Botucatu (FMB), Universidade Estadual Paulista (UNESP), Botucatu (SP), Brazil.

(D) orcid.org/0000-0002-4568-2389

"'MSc. Psychologist, Department of Public Health, Faculdade de Medicina de Botucatu (FMB), Universidade Estadual Paulista (UNESP), Botucatu (SP), Brazil.

(D) orcid.org/0000-0002-4750-5634

"vphD. Physician and Professor, Department of Public Health, Faculdade de Medicina de Botucatu (FMB), Universidade Estadual Paulista (UNESP), Botucatu (SP), Brazil.

(D) orcid.org/0000-0001-8392-9920

vPhD. Statistician and Methods and Statistics Consultant, Department of Public Health, Faculdade de Medicina de Botucatu (FMB), Universidade Estadual Paulista (UNESP), Botucatu (SP), Brazil.

(D) orcid.org/0000-0002-7806-1386

viPhD. Psychiatrist and Associate Professor, Department of Neurology, Psychology and Psychiatry, Faculdade de Medicina de Botucatu (FMB), Universidade Estadual Paulista (UNESP), Botucatu (SP), Brazil.

(D) orcid.org/0000-0002-1446-2439

KEY WORDS (MeSH terms):

Alcohol drinking.

Accidents, traffic.

Risk factors.

Cross-sectional studies.

Mental health

Psychopathology.

Epidemiology.

\section{AUTHORS' KEY WORDS:}

Alcohol and other drugs.

Neuroscience.

Gender and health.

\begin{abstract}
BACKGROUND: Harm to other people caused by an individual under the influence of alcohol (UIA) can occur in a variety of relationship situations between the drinker and these other people.

OBJECTIVES: To estimate the prevalence of the risk of vehicle accidents (RVA) involving people who are UIA, according to sociodemographic variables, respondent alcohol use and gender.

DESIGN AND SETTING: Cross-sectional study, in which a household survey was carried out on a cluster-stratified representative sample of urban residents in the city of São Paulo.

METHODS: The final sample was composed of 1,155 subjects aged 18-59 years, who were interviewed using the GENACIS Harm-to-Others questionnaire. Individuals were defined as having been harmed if an affirmative response was given to at least one of the questions that refers to RVA involving people who had been UIA in the last twelve months. Post-stratification weights were calculated to adjust for the study design and for no response. Since the outcome was binary, logistic regression was used in multivariable analysis. RESULTS: The final response rate was 58.6\%. The overall prevalence of RVA was 13.6\% (95\% confidence interval, Cl 11.0-16.7): $16.6 \%$ among men and 10.8\% among women. After the logistic regression, age remained as a protective factor (odds ratio, OR 0.95) and binge drinking as a risk factor (OR 2.03). CONCLUSION: This study showed that binge drinking was associated with RVA.
\end{abstract}

\section{INTRODUCTION}

Harm to other people caused by individuals who are under the influence of alcohol (UIA) can happen in many ways, to different degrees and to people with different relationships with the drinker. Harm to other people due to alcohol consumption can include intentional or unintentional injury and can affect a whole group or single individuals, who may be spouses, relatives, friends, non-relatives living in the same home, co-workers or even strangers. ${ }^{1-3}$

Studies have shown that traffic accidents and alcohol consumption are directly related, thereby causing serious consequences to individuals, families and the community. ${ }^{4-8}$ Brazil is one of the countries with the highest rates of traffic accidents relating to alcohol consumption, with huge social costs. ${ }^{4-8}$ A recent review by Araújo et al. ${ }^{9}$ assessed several studies on traffic accidents and alcohol use in Brazil, and showed that there was high prevalence of alcohol use and an association between this and the severity of injuries. A Brazilian survey conducted in 2012 indicated that the prevalence of individuals who reported driving after consuming alcohol in the last year was $27.3 \%$ among men and $7.1 \%$ among women. ${ }^{10}$

Epidemiological studies evaluating alcohol use relating to fatalities in the state of São Paulo, the Federal District and the city of Porto Alegre found alcohol in the blood in 45\%, 43\% and $32 \%$ of the subjects, respectively. Among non-fatal accident victims treated in trauma and emergency care centers in Uberlandia, state of Minas Gerais, $31.8 \%$ of these patients tested positive for blood alcohol content, and they more frequently required hospitalization $(70.4 \%$ versus $37.9 \%$; $\mathrm{P}$ < 0.05). ${ }^{11,12}$

A study carried out in the city of Rio de Janeiro showed that $42.5 \%$ of fatal traffic accidents involved individuals with some level of blood alcohol concentration, among which $66.2 \%$ had levels between 0.6 and $2.0 \mathrm{~g} / \mathrm{L}$ of alcohol in the blood. Four to eight doses of alcohol, on average, in the last hours before the accident may indicate excessive alcohol consumption. However, this study in Rio de Janeiro found that the frequency of blood alcohol tests was low: only $34.8 \%$ of 
all victims of traffic accidents underwent the test. This will have contributed to underreporting of the true numbers of alcohol-related accidents in traffic. ${ }^{13}$

A cross-sectional study developed in the emergency services of Brazilian state capitals and in the Federal District showed that among the cases from traffic accidents that were attended, especially those involving motorcycles, the proportion in which alcohol consumption was a factor ranged from $5.8 \%$ in Rio de Janeiro to $28.6 \%$ in Teresina (state of Piauí). ${ }^{14}$ The city of São Paulo, the setting of the present study, is situated in the southeastern region of Brazil, which is the region of this country with highest lifetime rate of alcohol use (80.4\%). ${ }^{15}$

In 2008, the Brazilian Congress approved law no. 11.705/2008, which reduced to zero the level of alcohol in blood that was permitted for drivers in this country.

The current study is part of GENAHTO, an acronym for Gender and Alcohol's Harm to Others. ${ }^{16}$ "GEN" signifies the importance of gender in studying the harm that alcohol causes to other people, along with the project's continuity with the GENACIS Project (Gender, Alcohol and Culture: an International Study). In the latter, several cross-sectional studies carried out in different countries had the aim of evaluating the patterns of alcohol use between men and women in different contexts and cultures, from a gender perspective., ${ }^{3,17}$

GENAHTO analyses are guided by a conceptual model in which the harm that alcohol causes to other people is examined within a nested multi-level set of potential influences. The central aspect of these analyses is the characteristics of individuals experiencing and causing this harm, such as gender and drinking patterns. These characteristics are entrenched in the individual's role relationships, social groups and drinking contexts and provide extensive data on harms due to others' drinking, from the victim's perspective. ${ }^{16}$ GENAHTO aims to contribute towards elaboration of preventive and interventional measures for problems relating to use of alcohol by men and women. Through this contribution, measures that are sensitive to gender issues and policies regarding alcohol use can be developed. This research is carried out through a standardized questionnaire, with adaptation to different cultures.

\section{OBJECTIVE}

The aim of the present study was to estimate the prevalence of the risk of vehicle accidents (RVA) involving people who were UIA, according to sociodemographic characteristics and respondent alcohol use.

\section{METHODS}

\section{Sample}

This study comprised a cross-sectional survey of the general population that was carried out on a cluster-stratified representative sample of urban residents of the city of São Paulo. The participants were aged 18 to 59 years. The sample was probabilistic.

Stratified sampling procedures were used in three stages: census tract, household and resident. Considering that only one resident in each household would be interviewed, 1,250 households were included in the sample. These households were distributed in 50 census tracts. In each census tract, 25 households were surveyed and, in each household, a single resident. To select this resident, we used the procedure proposed by Kish. ${ }^{18}$ Considering that empty dwellings would be found and that the refusal rate among the residents was likely to be $20 \%, 1,600$ households were drawn, i.e. 32 in each census tract. If the home was found to be unoccupied, a maximum of two further visits were made, to try to find a resident. The interviews were conducted between September 2014 and January 2015. The percentage of the households that received the interviewers was $71.0 \%$, but $17.5 \%$ of the households refused to participate, which resulted in a final response rate of $58.6 \%$.

\section{Setting}

The study site was the city of São Paulo, which is the capital of the state of São Paulo. This is the largest and the most populated city in Brazil and in the southern hemisphere. The Brazilian Institute for Geography and Statistics calculated the population of this municipality as $11,253,503$ inhabitants in 2010 . In this city, there were over 8.5 million registered motor vehicles in 2017; in 2016, there were 16,052 accidents, with 19,235 victims, including both fatal and non-fatal cases. ${ }^{19,20}$

\section{Dependent variable: risk of vehicle accidents (RVA)}

RVA was the dependent variable in this study. Individuals were defined as having been harmed if an affirmative response was given to at least one of the questions referring to vehicle accidents that involved people who were UIA, in the last twelve months. The dependent variable was constructed through the following questions:

- Have you ever been a passenger of a driver who had drunk a lot?

- Have you had a car accident (or other motor vehicle accident) because of someone else's drinking?

- Did you feel at risk in the car when someone else was driving, because of how much the person had drunk?

- Were you injured in a car accident because of how much someone else had drunk?

\section{Independent variables}

The instrument used for data-gathering was the GENACIS Harm-to-Others questionnaire (available upon request):

- Sociodemographic variables All sociodemographic characteristics, including the variables of gender, age, color, income and education were included in this study and were assumed to be independent for the analysis. 
- Respondent alcohol use

The respondents were questioned about their alcohol consumption. They were classified as abstinent (had never made use of alcohol in their lifetime), former drinker (had not used alcohol in the last 12 months) or current drinker (had had alcohol intake in the last 12 months. The drinkers reported their consumption in terms of quantity and frequency on a typical day. Binge drinking was also investigated, and this was considered to consist of consumption of four or more drinks for women and five or more drinks for men on one occasion in the last 12 months. For the analysis, the number of doses on a typical day, any occurrences of binge drinking and the score from the alcohol use disorders identification test (AUDIT) were included, for current drinkers only.

- AUDIT

The AUDIT ${ }^{21}$ is an instrument with 10 items that was designed to identify the patterns of alcohol use. It has been validated for use in Brazil. ${ }^{22}$ When respondents get a score of eight points or more, their consumption is considered to be at a problematic level of use. Although this test includes questions that identify binge drinking, its aim is to identify subjects who already present a problematic pattern of use, as defined by this instrument.

\section{Analytical model}

Associations between the outcome and independent variables were evaluated using the Rao-Scott test. ${ }^{23}$ Each observation was weighted accordingly to compensate for the effects of delineation and of no response. Firstly, we ran bivariate analyses, to select eligible variables for inclusion in multivariable analysis. We used multivariable logistic regression analysis, with backward stepwise variable selection. ${ }^{24}$ All the variables that showed associations with outcome presenting $\mathrm{P} \leq 0.25$ were included in the models.

The results from these analyses are presented in the form of odds ratios (OR), using 95\% confidence intervals (CI). Only variables for which the associations presented $\mathrm{P}<0.05$ were retained in the final model. We did separate analyses for men and women. The data were analyzed using the Stata 12.0 statistical software (StataCorp LP, College Station, TX, USA).

\section{Ethics}

The proposal for this study was approved by the Research Ethics Committee of the Medical School, Universidade Estadual Paulista (UNESP), on November 5, 2012 (protocol no. 4410-2012), and was supported by the Research Support Foundation of the State of São Paulo Research Program for the National Health System (Fundação de Amparo à Pesquisa do Estado de São PauloPrograma de Pesquisa para o SUS, FAPESP-PPSUS) (grant number 2012/51237-8).

\section{RESULTS}

The final sample was composed of 1,155 subjects, among whom there were 648 women (52.3\%) and 507 men (43.7\%). The final response rate was $58.6 \%$. The prevalence of RVA was $13.6 \%$ (95\% CI 11.0-16.7\%) and it was significantly higher among men $(\mathrm{P}=0.01)$ : $16.6 \%$ among men (95\% CI $12.0-21.2 \%)$ and $10.8 \%$ among women (95\% CI 8.1-13.5\%).

As mentioned earlier, bivariate analysis was run for each gender. Regarding demographic variables (Table 1), exposure to RVA due to alcohol use by other people was significantly higher among

Table 1. Risk of vehicle accidents involving people who were under the influence of alcohol in the last 12 months, according to sociodemographic characteristics $(n=1,155)$, city of São Paulo, 2014

\begin{tabular}{|c|c|c|c|c|c|c|}
\hline \multirow[t]{2}{*}{$\begin{array}{l}\text { Sociodemographic } \\
\text { characteristics }\end{array}$} & \multicolumn{3}{|c|}{$\begin{array}{l}\text { Risk of vehicle } \\
\text { accidents } \\
\text { Males }(n=507)\end{array}$} & \multicolumn{3}{|c|}{$\begin{array}{c}\text { Risk of vehicle } \\
\text { accidents } \\
\text { Females }(n=648)\end{array}$} \\
\hline & n & $\%$ & $P^{*}$ & n & $\%$ & $\mathrm{P}^{*}$ \\
\hline Age & & & $<0.001$ & & & 0.72 \\
\hline$<30$ & 41 & 29.0 & & 20 & 12.4 & \\
\hline 30 to 49 & 37 & 12.9 & & 33 & 9.9 & \\
\hline$\geq 50$ & 4 & 4.0 & & 12 & 10.6 & \\
\hline Color & & & 0.83 & & & 0.68 \\
\hline White & 33 & 17.1 & & 34 & 11.4 & \\
\hline Nonwhite & 49 & 16.2 & & 31 & 10.2 & \\
\hline Marital status & & & 0.004 & & & 0.25 \\
\hline Married & 28 & 10.5 & & 28 & 9.1 & \\
\hline $\begin{array}{l}\text { Widowed/divorced/ } \\
\text { separated }\end{array}$ & 6 & 14.4 & & 12 & 9.7 & \\
\hline Single & 48 & 24.4 & & 25 & 13.5 & \\
\hline Education & & & 0.04 & & & 0.20 \\
\hline Only elementary school & 4 & 8.7 & & 11 & 11.0 & \\
\hline Incomplete high school & & & & & & \\
\hline $\begin{array}{l}\text { to incomplete college/ } \\
\text { university }\end{array}$ & 55 & 20.3 & & 40 & 12.7 & \\
\hline $\begin{array}{l}\text { Completed college/ } \\
\text { university or more }\end{array}$ & 23 & 12.8 & & 14 & 6.6 & \\
\hline Children & & & 0.01 & & & 0.79 \\
\hline Yes & 36 & 11.2 & & 46 & 10.6 & \\
\hline No & 46 & 22.9 & & 19 & 11.2 & \\
\hline Current work status & & & 0.03 & & & 0.62 \\
\hline Employee or self-employed & 66 & 15.5 & & 44 & 11.2 & \\
\hline Retired & 1 & 7.1 & & 2 & 15.9 & \\
\hline Unemployed & 11 & 21.2 & & 11 & 12.1 & \\
\hline Student & 4 & 46.6 & & 2 & 14.2 & \\
\hline Housekeeper & 0 & 0 & & 6 & 5.9 & \\
\hline Monthly family income & & & 0.82 & & & 0.77 \\
\hline 0 to 3 minimum wages & 47 & 16.5 & & 45 & 10.9 & \\
\hline$>3$ minimum wages & 33 & 15.6 & & 16 & 10.1 & \\
\hline $\begin{array}{l}\text { Education level of the person } \\
\text { responsible for family income }\end{array}$ & & & 0.45 & & & 0.01 \\
\hline Only elementary school & 26 & 12.5 & & 12 & 5.1 & \\
\hline Incomplete high school & & & & & & \\
\hline $\begin{array}{l}\text { to incomplete college/ } \\
\text { university }\end{array}$ & 40 & 18.1 & & 42 & 14.0 & \\
\hline $\begin{array}{l}\text { Completed college/ } \\
\text { university or more }\end{array}$ & 13 & 19.3 & & 11 & 11.6 & \\
\hline
\end{tabular}

*Rao-Scott test. Percentages were calculated considering weights for non-response and for study design. 
the following groups of men: those who were younger (29.0\%), single $(24.4 \%)$, with schooling levels ranging from incomplete high school to incomplete college/university (20.3\%), with no children (22.9\%) and students (46.6\%). Among women, only the education level of the person responsible for the family income was significant $(\mathrm{P}=0.01)$. RVA was most prevalent among individuals whose schooling level ranged from incomplete high school to incomplete college/university (14.0\%).

As shown in Table 2, among men, occurrences of vehicle accidents involving people who were UIA in the last 12 months were associated with being a current drinker (19.2\%). It is noteworthy that, for this variable, a dose-response effect could be seen among lifetime abstainers, former drinkers and current drinkers. In addition, reporting occurrences of consumption of five or more alcoholic beverages on a single occasion in the last 12 months (26.2\%), consuming five or six drinks on a typical day (30.3\%) and AUDIT scores of eight or more points (29.2\%) were associated with RVA.

Among women, occurrences of vehicle accidents involving people who were UIA in the last 12 months were associated with being a current drinker (16.3\%) and high frequency of alcohol consumption in the last 12 months $(\mathrm{P}=0.001)$.

For the multivariable analysis, it was decided to build a single model for both genders together. All the variables selected were included in the model and they were retained if $\mathrm{P}>0.05$. In order to highlight the importance of binge drinking, we presented two models (Table 3). In the first model, only gender and age were included, and this showed the risk associated with male gender $(\mathrm{OR}=1.64)$ and the protective effect of increasing age. In the second model, binge drinking was included and this nullified the risk associated with male gender. It was observed that the binge drinking variable was a risk factor $(\mathrm{OR}=2.38)$ and that its introduction changes the OR values for gender, thus changing its significance. Also, the inclusion of binge drinking did not prejudice the role of age, which remained a protective factor.

\section{DISCUSSION}

Social harms from drinking are inherently interactional. For social harm to be recognized as occurring, there needs to be not only drinking behavior that is seen as problematic, but also a reaction by someone other than the drinker. The harm may occur to the drinker or to other people. ${ }^{25}$ Alcohol surveys have usually asked drinkers themselves about problems from their own drinking. However, it is important to investigate people who have been harmed by other people's drinking. ${ }^{26}$

The total percentage of individuals who reported occurrences of RVA in the present study was $12.73 \%$. Using data from the 2014 to 2015 United States National Alcohol Survey, KarrikerJaffe et al. ${ }^{27}$ found that fewer than $1 \%$ of the respondents had been in traffic accidents caused by someone who had been drinking, in the last year.
Table 2. Risk of vehicle accidents involving people who were under the influence of alcohol in the last 12 months according to alcohol consumption and according to gender, city of São Paulo, 2014

\begin{tabular}{|c|c|c|c|c|c|c|}
\hline \multirow[t]{2}{*}{ Risk factor } & \multicolumn{3}{|c|}{$\begin{array}{l}\text { Risk of vehicle } \\
\text { accidents } \\
\text { Males ( } n=507 \text { ) }\end{array}$} & \multicolumn{3}{|c|}{$\begin{array}{c}\text { Risk of vehicle } \\
\text { accidents } \\
\text { Females }(n=648)\end{array}$} \\
\hline & $n$ & $\%$ & $\mathbf{P}$ & n & $\%$ & $\mathbf{P}$ \\
\hline Alcohol consumption & & & 0.008 & & & \\
\hline Abstinent & 1 & 1.5 & & 11 & 5.7 & \\
\hline Former drinker & 13 & 14.6 & & 10 & 5.6 & 0.0001 \\
\hline Current drinker & 68 & 19.2 & & 44 & 16.3 & \\
\hline
\end{tabular}

Frequency of alcohol consumption in

the last 12 months

0.35

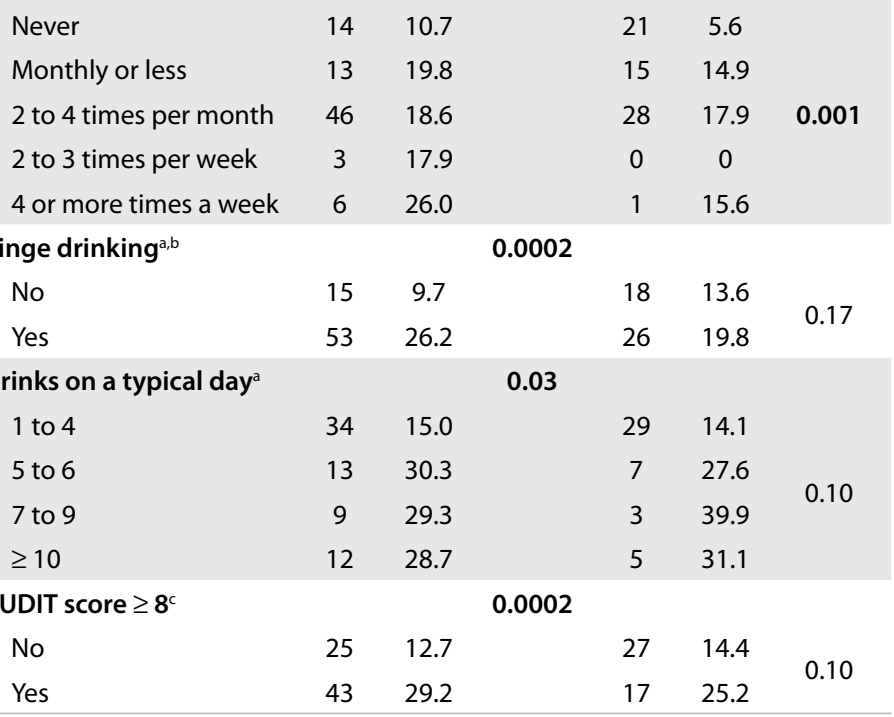

AUDIT = alcohol use disorders identification test.

Percentages were calculated considering weights for non-response and for study design. Information only among drinkers; bour or more drinks for women and five or more drinks for men on one occasion in the last 12 months; ${ }^{c}$ Alcohol use identification test.

Table 3. Logistic regression for risk of vehicle accidents involving people who were under the influence of alcohol in the last 12 months, city of São Paulo, 2014 ( $n=1,155)$

\begin{tabular}{lccccc} 
& $\begin{array}{c}\text { Crude odds } \\
\text { ratio }\end{array}$ & $\begin{array}{c}\text { Confidence } \\
\text { interval }\end{array}$ & $\begin{array}{c}\text { Adjusted } \\
\text { odds ratio }\end{array}$ & $\begin{array}{c}\text { Confidence } \\
\text { interval }\end{array}$ & P \\
\hline $\begin{array}{l}\text { Model } 1 \\
\text { Age }\end{array}$ & 0.96 & $0.94-0.98$ & 0.96 & $0.94-0.98$ & $<0.001$ \\
$\begin{array}{l}\text { Gender } \\
\quad \text { Female }\end{array}$ & 1 & - & - & - & \\
$\quad \begin{array}{l}\text { Male } \\
\text { Model 2 }\end{array}$ & 1.64 & $1.11-2.41$ & 1.61 & $1.13-2.32$ & $<0.01$ \\
$\begin{array}{l}\text { Age } \\
\text { Sex }\end{array}$ & 0.96 & $0.94-0.98$ & 0.95 & $0.93-0.98$ & $<0.001$ \\
$\quad \begin{array}{l}\text { Female } \\
\text { Male }\end{array}$ & 1 & - & - & - & \\
\hline $\begin{array}{l}\text { Binge } \\
\text { drinking }\end{array}$ & 1.64 & $1.11-2.41$ & 1.11 & $0.75-1.66$ & 0.60 \\
\hline
\end{tabular}

aFour or more drinks for women and five or more drinks for men on one occasion in the last 12 months. 
The main outcome of the present study was that a significant association was found between higher prevalence of risks of vehicle accidents (RVA) and binge drinking, caused by other people's consumption. In other words, when drinkers practice binge drinking, they put themselves at risk, regardless of whether or not they are the driver. A causal link has been shown between consumption of alcoholic beverages and occurrences of traffic accidents, considering the effects of alcohol on individuals' perception, vision, reflexes, consciousness and behavior. ${ }^{28}$ A study conducted in all Brazilian state capitals and the Federal District showed that the percentage of the subjects who had consumed any amount of alcohol before driving was 5.3\% in 2011 and $7.3 \%$ in 2016. ${ }^{29}$ The first National Household Survey on Alcohol Consumption Patterns, which was applied in 143 Brazilian cities between 2005 and 2006, indicated that $34.7 \%$ of motorists drank and drove in the last 12 months. ${ }^{6}$ Data from 2008 for the adult population of 27 cities showed that $1.5 \%$ of individuals reported having driven a motor vehicle after excessive alcohol consumption, on at least one occasion in the last 30 days. $^{7}$ One study found that $41.2 \%$ of the 431 victims of fatal motor vehicle accidents over 16 years of age who were admitted to the Institute of Legal Medicine of the Federal District (IML-DF) presented a blood alcohol concentration above $0.6 \mathrm{~g} / \mathrm{l}^{1{ }^{11}}$

In the present study, it was observed that age was a protective factor, such that RVA decreased with increasing age. The practice of driving after excessive alcohol consumption showed highest frequency in the 25 to 34 -year age group (4.0\% among men and $0.7 \%$ among women). ${ }^{7}$ Duailibi et al. $^{8}$ studied drivers between 21 and 30 years old, on weekend nights in Diadema (SP) and observed that more than $20 \%$ of the drivers undergoing the breathalyzer had breath alcohol levels above $0.01 \mathrm{~g} / \mathrm{dl}$.

In Brazil, violent deaths, including homicides, traffic accidents and suicides represent about $70 \%$ of deaths among people between 15 and 24 years of age. This number places Brazil among the 10 countries where traffic accidents are responsible for more than $60 \%$ of deaths. ${ }^{30}$

Brazilian data from the telephone-survey surveillance system for risk factors and protective factors relating to chronic diseases (Sistema de Vigilância de Fatores de Risco e Proteção para Doenças Crônicas por Inquerito Telefônico, VIGITEL) for the period from February to December 2016 showed that the rate of alcohol abuse had increased from $15.7 \%$ to $19.1 \%$ over the preceding ten-year period. ${ }^{29}$ The second National Survey of Alcohol and Drugs, conducted among individuals aged 14 years and over, investigated consumption rates of five doses or more for men and four doses or more for women, on a single occasion within a period of up to 2 hours, in the last 12 months. The data showed prevalences of $45 \%$ in 2006 and $58 \%$ in 2012 , i.e. increasing from $54 \%$ to $66 \%$ among men and from $34 \%$ to $48 \%$ among women. ${ }^{10}$
Although gender did not remain significant after multivariable analysis in the present study, data in the literature show that men are more likely than women to binge-drink and to drive after doing so. Data from a telephone survey among adults in the United States aged 18 years and over found that $75.1 \%$ of binge drinkers were men and that $49.7 \%$ consumed seven or more drinks during their most recent binge-drinking episode. In the gender-based assessment, men were more likely than women to drive after binge drinking (13.2\% versus $8.1 \%$ ), and men accounted for $82.9 \%$ of all recent binge drinking and driving episodes. ${ }^{31}$

In the $60^{\text {th }}$ World Health Assembly in 2007, binge drinking was shown to be responsible for $3.7 \%$ of deaths and was associated with $4.4 \%$ of diseases in the world. Thus, binge drinking is a public health problem and monitoring it is essential in order to find out about consumption patterns and ascertain which segments of the population are more vulnerable. These data are fundamental for formulating and funding public policies for health promotion and prevention of risky behavior. ${ }^{32}$

One possible limitation of the present study was the higher non-response rate among men and especially in census tracts with middle-to-high income. Higher non-response rates can be expected in large urban centers, especially in those with high incidence of violence and fear of this situation. However even developed countries can have low response rates: in a similar study carried out in Ireland, the response rate was 37\%; while in Australia it was 38\%. ${ }^{16}$ There is no consensus regarding the minimum response rate for population surveys, taking into account the characterization of non-responders, or regarding the extent to which this loss relates to the information sought by the study. Since the subject of RVA is a sensitive issue, we can assume that there is a risk minimization factor: probably the risk is greater than what has been found.

Our data differ from those of some other studies that indicated high abstinence rates in Brazil, especially in populations with lower levels of education. ${ }^{33,34}$ It is possible that this result is related to the questionnaire that was used. The GENACIS Harm-to-Others questionnaire assesses the frequency of alcohol consumption through detailed questions about different types of alcoholic beverages, with the aim of minimizing biases in memory, misrepresentation, false responses or non-acceptance, which are common in surveys on embarrassing or intimate issues.

Nonetheless, the figures obtained in the present study are close to the national data, which indicate that the prevalence of drinkers is around $50 \% .{ }^{10}$ Also, as previously mentioned, the city of São Paulo is characterized by a peculiar situation, in that it is located in the region with highest lifetime rate of alcohol use (80.4\%). ${ }^{15}$

The strengths of this study, on the other hand, are that it was conducted over a short period, was stratified according to neighborhoods and had a representative sample of residents of the city of São Paulo, between 18 and 59 years of age. Thus, the results can 
be generalized to other large urban centers and probably do not reflect the patterns of rural areas of Brazil.

The problems arising from consumption of alcoholic drinks by drivers have been studied internationally in a broad manner. In Brazil, the risk of vehicle accidents associated with alcohol use can be considered to be a major public health problem, with a major impact on morbidity and mortality, especially in the young male population. Therefore, preventive interventions need to focus on these problems, for instance through promoting strict enforcement of drinking and driving laws to prevent this combination of behaviors.

\section{CONCLUSIONS}

GENAHTO is the first project to assess the harm that alcohol use causes to other people in diverse societies. ${ }^{16}$ The current study aimed to estimate the prevalence of the risk of vehicle accidents involving people who were under the influence of alcohol, and it attempted to fill the gap regarding the lack of studies on people who are victims in accidents involving alcohol consumption by other people. It is important to highlight that we found that individuals who practiced binge drinking put themselves in RVA situations, regardless of whether they are the driver or not. Until now, this impact has not been considered in establishing public policies regarding alcohol consumption. This indicates that there is a need for further studies in this important area, and the results from the present study could be useful for guiding preventive strategies.

\section{REFERENCES}

1. Karriker-Jaffe KJ, Li L, Greenfield TK. Estimating mental health impacts of alcohol's harms from other drinkers: using propensity scoring methods with national cross-sectional data from the United States. Addiction. 2018;113(10):1826-39. PMID: 29893009; doi: 10.1111/add.14283.

2. Laslett AM, Room R, Ferris J, et al. Surveying the range and magnitude of alcohol's harm to others in Australia. Addiction. 2011;106(9):1603-11. PMID: 21438943; doi: 10.1111/j.1360-0443.2011.03445.x.

3. de Oliveira JB, Lima MC, Simão MO, et al. Violência entre parceiros íntimos e álcool: prevalência e fatores associados [Violence between intimate partners and alcohol use: prevalence and associated factors]. Rev Panam Salud Publica. 2009;26(6):494-501. PMID: 20107703; doi: 10.1590/s1020-49892009001200004.

4. Malta DC, Berna RT, Silva MM, et al. Consumo de bebidas alcoólicas e direção de veículos, balanço da lei seca, Brasil 2007 a 2013 [Consumption of alcoholic beverages, driving vehicles, a balance of dry law, Brazil 2007-2013]. Rev Saude Publica. 2014;48(4):692-966. PMID: 25210828; doi: 10.1590/s0034-8910.2014048005633.

5. Bacchieri G, Barros AJ. Traffic accidents in Brazil from 1998 to 2010 : many changes and few effects. Rev Saude Publica. 2011;45(5):949-63. PMID: 21953026; doi: 10.1590/s0034-89102011005000069.

6. Pechansky F, De Boni R, Diemen LV, et al. Highly reported prevalence of drinking and driving in Brazil: data from the first representative household study. Braz J Psychiatry. 2009;31 (2):125-30. PMID: 19578684; doi: 10.1590/s1516-44462009000200008.

7. Moura EC, Malta DC, Morais Neto OL, Penna GO, Temporão JG. Motor vehicle driving after binge drinking, Brazil, 2006 to 2009. Rev Saude Publica. 2009;43(5):891-4. PMID: 19784459; doi: 10.1590/s003489102009005000062.

8. Duailibi S, Pinsky I, Laranjeira R. Prevalência do beber e dirigir em Diadema, estado de São Paulo [Prevalence of drinking and driving in a city of Southeastern Brazil]. Rev Saude Publica. 2007;41(6): 1058-61. PMID: 17923887; doi: 10.1590/s0034-89102006005000045.

9. Araújo TA, Oliveira ADS, Souza IBJ, et al. Acidentes de trânsito e sua relação com o consumo de álcool: revisão integrativa [Traffic accidents and their relationship with alcohol use: integrative review]. J Nurs UFPE online. 2015;9(Suppl 5):8437-43. doi: 10.5205/reuol.6466-55061-3SM.0905supl201513.

10. Ronaldo Laranjeira, supervision. II Levantamento Nacional de Álcool e Drogas (LENAD). São Paulo: Instituto Nacional de Ciência e Tecnologia para Políticas Públicas de Álcool e Outras Drogas (INPAD), UNIFESP; 2014. Available from: https://inpad.org.br/wp-content/uploads/2014/03/ Lenad-II-Relat\%C3\%B3rio.pdf. Accessed in 2019 (Nov 6).

11. Santos Modelli ME, Pratesi R, Tauil PL. Alcoolemia em vítimas fatais de acidentes de trânsito no Distrito Federal, Brasil [Blood alcohol concentration in fatal traffic acidentes in the Federal District, Brazil]. Rev Saude Publica. 2008;42(2):350-2. PMID: 18327493; doi: 10.1590/ s0034-89102008000200022.

12. Freitas EA, Mendes ID, Oliveira LC. Ingestão alcoólica em vítimas de causas externas atendidas em um hospital geral universitário [Alcohol consumption among victims of external causes in a university general hospital]. Rev Saude Publica. 2008;42(5):813-21. PMID: 18833382; doi: 10.1590/S0034-89102008000500005.

13. Abreu AMM, Lima JMB, Griep RH. Acidentes de trânsito e a frequência dos exames de alcoolemia com vítimas fatais na cidade do Rio de Janeiro [Traffic accidents with fatal victims and alcohol consumption in Rio de Janeiro City]. Esc Anna Nery. 2009;13(1):44-50. doi: 10.1590/ S1414-81452009000100007.

14. Malta DC, Bernal RT, Mascarenhas MDM, et al. Atendimentos por acidentes de transporte em serviços públicos de emergência em 23 capitais e no Distrito Federal - Brasil, 2009 [Traffic accident emergency medical care by emergency services in 23 state capitals and the Federal District - Brazil, 2009]. Epidemiol Serv Saude. 2012;21(1):31-42. doi: 10.5123/S1679-49742012000100004.

15. Carlini EA, supervision. II levantamento domiciliar sobre o uso de drogas psicotrópicas no Brasil: estudo envolvendo as 108 maiores cidades do país: 2005. São Paulo: CEBRID - Centro Brasileiro de Informações Sobre Drogas Psicotrópicas: UNIFESP - Universidade Federal de São Paulo; 2006. p. 472. Available from: https://www. cebrid.com.br/wp-content/uploads/2014/10/II-LevantamentoDomiciliar-sobre-o-Uso-de-Drogas-Psicotr\%C3\%B3picas-no-Brasil. pdf. Accessed in 2019 (Nov 6). 
16. Wilsnack SC, Greenfield TK, Bloomfield K. The GENAHTO Project (Gender and Alcohol's Harm to Others): Design and methods for a multinational study of alcohol's harm to persons other than the drinker. Int J Alcohol Drug Res. 2018;7(2):37-47. PMID: 30740190; doi: 10.7895/ijadr.253.

17. Cavariani MB, Oliveira JB, Kerr-Corrêa F, Lima MC. Expectativas positivas com o uso de álcool e o beber se embriagando: diferenças de gênero em estudo do Projeto GENACIS, São Paulo, Brasil [Positive expectations towards alcohol use and binge drinking: gender differences in a study from the GENACIS Project, São Paulo, Brazil]. Cad Saude Publica. 2012;28(7):1394-404. PMID: 22729269; doi: 10.1590/s0102$311 \times 2012000700017$.

18. Kish L. A procedure for objective respondent selection within the household. J Am Stat Assoc. 1949;44(247):380-7. Available from: https:// amstat.tandfonline.com/doi/abs/10.1080/01621459.1949.10483314\#. Xm-5xahKiUk. Accessed in 2020 (Mar 16).

19. Departamento Estadual de Trânsito de São Paulo (DETRAN) - 2017 [Internet]. Frota de veículos em São Paulo. Available from: https:// www.detran.sp.gov.br/wps/wcm/connect/portaldetran/detran/ detran/estatisticastransito/sa-frotaveiculos/d28760f7-8f21-429f-b0390547c8c46ed1. Accessed in 2019 (Nov 7).

20. Companhia de Engenharia de Tráfego (CET), Secretaria Municipal de Mobilidade e Transportes, Prefeitura Municipal de São Paulo [Internet]. Acidentes de trânsito - Relatório anual; 2016. Available from: http://www. cetsp.com.br/media/562061/relatorioanualacidentestransito-2016.pdf. Accessed in 2019 (Nov 6).

21. Babor TF, Higgings-Biddle JC, Saunders JB, Monteiro MG. The Alcohol Use Disorders Identification Test: Guidelines for use in primary health care. $2^{\text {nd }}$ edition. Geneva: World Health Organization; 2001.

22. Santos WS, Gouveia WV, Fernandes DP, Souza SSB, Grangeiro ASM. Alcohol Use Disorder Identification Test (AUDIT): explorando seus parâmetros psicométricos [Alcohol Use Disorder Identification Test (AUDIT): exploring its psychometric parameters]. J Bras Psiquiatr. 2012; 61(3):117-23. doi: 10.1590/S0047-20852012000300001.

23. Rao JNK, Scott AJ. On Chi-squared tests for multiway contingency tables with cell proportions estimated from survey data. The Annals of Statistics. 1984;12(1):46-60. Available from: https://projecteuclid.org/ download/pdf_1/euclid.aos/1176346391. Accessed in 2019 (Nov 6).

24. Hosmer DW, Lemeshow S. Applied Logistic Regression. New York: Wiley; 1989.

25. Room R, Ferris J, Laslett AM, et al. The drinker's effect on the social environment: a conceptual framework for studying alcohol's harm to others. Int J Environ Res Public Health. 2010;7(4):1855-71. PMID: 20617064; doi: 10.3390/ijerph7041855.

26. Callinan S, Laslett AM, Rekve D, et al. Alcohol's harm to others: An international collaborative Project. Int J Alcohol Drug Res. 2016;5(2):2532. doi: 10.7895/ijadr.v5i2.218.

27. Karriker-Jaffe KJ, Greenfield TK, Kaplan LM. Distress and alcohol-related harms from intimates, friends, and strangers. J Subst Use. 2017;22(4):43441. PMID: 28757806; doi: 10.1080/14659891.2016.1232761.
28. Cunha FV, Julien TMS, Santos JCS. Characterization of car accidents in the city of Guaratinguetá, Brazil involving motorcycles. J Nurs UFPE online. 2011;5(5):1112-20. doi: 10.5205/reuol.1302-9310-2-LE.0505201105.

29. Ministério da Saúde. Vigitel Brasil 2016: vigilância de fatores de risco e proteção para doenças crônicas por inquérito telefônico - estimativas sobre frequência e distribuição sócio-demográfica de fatores de risco e proteção para doenças crônicas nas capitais dos 26 estados brasileiros e no Distrito Federal em 2016. [Internet]. Brasília: Ministério da Saúde, 2017. 160p. Available from: http://portalarquivos.saude. gov.br/images/pdf/2017/junho/07/vigitel_2016_jun17.pdf. Accessed in 2019 (Nov 6).

30. de Morais Neto OL, Montenegro Mde M, Monteiro RA, et al. Mortalidade por Acidentes de Transporte Terrestre no Brasil na última década: tendência e aglomerados de risco [Mortality due to Road Traffic Accidents in Brazil in the last decade: trends and risk clusters]. Cien Saude Colet. 2012;17(9):2223-36. PMID: 22996872; doi: 10.1590/s141381232012000900002.

31. Naimi TS, Nelson DE, Brewer RD. Driving after binge drinking. Am J Prev Med. 2009;37(4):314-20. PMID: 19765503; doi: 10.1016/j. amepre.2009.06.013.

32. World Health Organization (WHO). Drinking and driving: a road safety manual for decision-makers and practitioners. [Internet]. Geneva: Global Road Safety Partnership; 2007. Available from: http://www.who.int/ roadsafety/projects/manuals/alcohol/0-Introduction.pdf. Accessed in 2019 (Nov 6).

33. Laranjeira R, Pinsky I, Sanches M, Zaleski M, Caetano R. Alcohol use patterns among Brazilian adults. Braz J Psychiatry. 2010;32(3):231-41. PMID: 19918673; doi: 10.1590/s1516-44462009005000012.

34. Kerr-Corrêa F, Hegedus AM, Sanches AF, et al. Differences in drinking patterns between men and women in Brazil. In: Obot I, Room R, editors. Alcohol, gender and drinking problems: perspectives from low and middle-income countries and drinking problems. Geneva:World Health Organization; 2005. p. 49-68.

\section{Authors' contributions: Oliveira JB, Kerr-Côrrea F and Lima MCP} contributed through conception and planning of the study; data analysis and interpretation; and drafting of the manuscript. Lopes IC, Vitti Junior W and Nunes HRC contributed through data interpretation and drafting of the manuscript. All the authors approved the final version to be published and gave their agreement to be accountable for all aspects of the work, so as to ensure that questions relating to the accuracy or integrity of any part of the work are appropriately investigated and resolved

\section{Date and venue of the event at which the paper was presented:}

This study formed part of the data of Janaina Barbosa de Oliveira's postdoctoral report, presented to the Department of Public Health, Medical School, Universidade Estadual Paulista "Júlio de Mesquita Filho" (UNESP), Botucatu (SP), Brazil, in 2016 
Sources of funding: The present study had support from Fundação de

Amparo à Pesquisa do Estado de São Paulo-Políticas Públicas para o

Sistema Único de Saúde (FAPESP-PPSUS) (2012/51237-8)

Conflict of interest: None

Date of first submission: November 1, 2019

Last received: December 25, 2019

Accepted: January 27, 2020

Address for correspondence:

Janaina Barbosa de Oliveira

Centro de Estudos da Educação e da Saúde, Centro Especializado em

Reabilitação (CEES/CER II)

Universidade Estadual Paulista Julio de Mesquita Filho (UNESP)

Av. Hygino Muzzi Filho, 737

Mirante - Marília (SP) - Brasil

CEP 17525-900

Tel. (+55 14) 3402-1300

E-mail: janainabarbosadeoliveira@outlook.com 